\title{
Phân lập và nhận diện vi khuẩn phân giải nitrat trong dưa cải muối chua (Brassica juncea Coss)
}

\section{Isolation and identification of the denitrifying bacteria from fermented cabbage (Brassica juncea Coss)}

Võ Thị Xuân Hương ${ }^{1}$, Trương Phước Thiên Hoàng ${ }^{1}$, Nguyễn Ngọc Bảo Châu ${ }^{2}$, Nguyễn Bảo Quốc ${ }^{1 *}$

${ }^{1}$ Trường Đại học Nông Lâm Thành Phố Hồ Chí Minh, Việt Nam

${ }^{2}$ Trường Đại học Mở Thành phố Hồ Chí Minh, Việt Nam

*Tác giả liên hệ, Email: baoquoc@hcmuaf.edu.vn

THÔNG TIN

\section{TÓM TẮT}

DOI: $10.46223 / \mathrm{HCMCOUJS.}$ tech.vi.13.1.450.2018

Ngày nhận: 31/07/2018

Ngày nhận lại: 07/10/2018

Duyệt đăng: 15/10/2018

Tù khóa:

Bacillus aryabhattai, cải muối chua, vi khuẩn phân giải nitrate
Nghiên cứu được tiến hành thu thập các mẫu dưa cải (Brassica juncea Coss) tại chợ Thủ Đức - Thành phố Hồ Chí Minh, sau đó xác định hàm lượng nitrat theo ngày ủ chua bằng phương pháp so màu với Natri salixylat. Từ 10 mẫu dưa cải khác nhau được thu thập tại chợ tiến hành phân lập, tuyển chọn vi khuẩn có khả năng phân giải nitrat trên môi trường đặc trưng Giltay chứa cơ chất là $\mathrm{KNO}_{3}$, kết hợp với kiểm tra các đặc tính sinh hóa của các chủng phân lập được, kết quả thí nghiệm cho thấy hàm lượng nitrat của 10 mẫu dưa cải trên thị trường cho thấy hàm lượng nitrat không đạt tiêu chuẩn có hàm lượng $2.000-5.000 \mathrm{mg} / \mathrm{kg}$ theo quy định của Tổ chức $Y$ tế thế giới (WHO) ở các ngày thứ nhất, hai và ba trong thời gian lên men và chỉ tiêu đạt tiêu chuẩn sau 4 và 5 ngày lên men. Quá trình phân lập vi sinh phản nitrat đã sàng lọc được 6 dòng vi khuẩn có khả năng khử nitrat trên môi trường Giltay và tuyển chọn 2 dòng vi khuẩn có khả năng khử nitrate cao khi nuôi cấy trên môi trường dịch thể nitrat. Kết quả khảo sát hàm lượng nitrat trong dưa cải ở các mẫu bổ sung vi khuẩn M1, M2 cho thấy hàm lượng nitrate thấp hơn so với những mẫu không bổ sung vi khuẩn. Tiến hành giải trình tự, so sánh và phân tích phả hệ thư mục di truyền phát sinh loài theo phương pháp Neighborjoining xác định loài vi khuẩn có khả năng chuyển hóa nitrate là Bacillus aryabhattai.

\section{ABSTRACT}

The study was conducted to evaluate the nitrate reduction in fermented mustard cabbage and determine the nitrate level during the fermentation process. A total of 10 samples of fermented 
Keywords:

Bacillus aryabhattai, denitrifying bacteria, fermented cabbage mustard cabbage were collected from some retailers at Thu Duc market. The samples were used to determine the nitrate concentration using color compared with sodium salicylate. Then we isolated and cultured the strains of nitrate-reducing bacteria in a specific Giltay medium containing $\mathrm{KNO}_{3}$, as well as testing biochemical characteristics. The cabbage was fermented with additional nitrate-decomposing bacteria and the nitrate concentration was compared with the control treatment. The experimental results showed that the nitrate level of the 10 collected samples of fermented cabbage varied between 2.000 $5.000 \mathrm{mg} / \mathrm{kg}$, exceeding the allowable level of the World Health Organization (WHO), during the three first days of the fermentation. The standard indicators were achieved after 4 and 5 days of the fermentation. In this study, we isolated at least 6 bacterial strains capable of reducing nitrate in a Giltay medium and selected two bacterial strains from others. The results of sequencing, identification and phylogenetic analysis based on NJ method showed that two strains of denitrifying bacteria are Bacillus aryabhattai.

\section{1. Đặt vấn đề}

Dưa cải muối chua là một loại rau lên men truyền thống ở Việt Nam từ cải bẹ dưa muối (Brassica juncea Coss), hệ vi sinh khuẩn acid lactic trong loại rau lên men này bị ảnh hưởng bởi các quá trình lên men khác nhau và điều kiện môi trường, (Chao, $\mathrm{Wu}$, Watanabe, \& Tsai, 2013). Đối với các loại rau cải thường sử dụng phân đạm urê để chăm bón, quá trình lên men sẽ khiến hàm lượng nitrat có trong rau bị khử thành nitrite. Quá trình lên men nitrat trong mô thực vật chuyển thành nitrite, nồng độ nitrite tăng theo thời gian, tăng cao trong vài ngày đầu và giảm dần khi dưa đã vàng và tăng cao trở lại khi dưa bị hư hỏng (Park \& Cheigh, 1992; Spoelstra, 1985). Số lượng nhiều nitrat tiêu thụ gián tiếp qua thực phẩm có thể gây hại cho sức khỏe (Chan, 2011; Leszczynska, Filipiak-Florkiewicz, Ciéslik, \& Sikora, 2009). Trong hệ thống tiêu hóa, nitrat có thể chuyển đổi thành nitrit do đó phản ứng với các amin sản xuất các hợp chất N-nitroso như Nitrosamin có khả năng gây ung thư ở dạ dày (Santamaria, 2006; Yordanov, Novakova, \& Lubenova, 2001). Nitrit còn là một trong những chất chuyển biến oxyhemoglobin thành chất không hoạt động được gọi là Methemoglobin làm giảm quá trình vận chuyển oxy trong máu (Greer, Shannon, American academy of pediatrics committee on nutrition, \& American academy of pediatrics committee on environmental health, 2005; Le \& Nguyen, 2012). Đặc biệt, rau lên men nằm trong danh sách của tổ chức Y tế thế giới cảnh báo có chất gây ung thư (World Health Organization, 2012).

Quá trình lên men lactic trong rau quả muối chua là kết quả hoạt động của một số vi khuẩn và một số nấm men, ví dụ như trong bắp cải hoạt động mạnh là Bacillus brassicae fermentati, Lactobacillus brevis, Leuconostoc mesenteroides, Luteimonas cucumeris và Lactobacillus pentoaceticus. Quá trình lên men lactic còn có thể gây ra bởi B. leichmani, B. 
beyerincki, $B$. ventricoccus và một số vi sinh vật khác. Các vi sinh vật lactic có hoạt động khác nhau nên cường độ lên men lactic của sản phẩm phụ thuộc vào hệ vi sinh vật có trong đó. Dạng của hệ vi sinh vật cũng ảnh hưởng tới tính chất đặc trưng của sản phẩm cuối cùng của quá trình phân hủy đường (Quach, Nguyen, \& Nguyen, 2008).

Quy trình lên men làm dưa cải muối chua bán ra thị trường ở Việt Nam được thực hiện khác nhau tuỳ theo vùng, miền, và nếu sản phẩm bán trên thị trường được lên men không đúng quy trình sẽ gây nguy hiểm đến sức khoẻ của con người. Do đó, việc loại bỏ hoặc làm giảm nitrat trong thực phẩm trước khi đưa vào sử dụng là rất cần thiết. Nghiên cứu nhằm mục đích phân lập, tuyển chọn và định danh các dòng vi khuẩn phân giải được hàm lượng nitrat có trong dưa muối chua và ứng dụng chúng để lên men dưa muối chua tại chợ Thủ Đức, Thành phố Hồ Chí Minh.

\section{Vật liệu và phương pháp}

\subsection{Vật liệu}

- Nguyên liệu: 10 mẫu dưa cải mới muối chua trong vòng 24h sử dụng trong nghiên cứu được thu mua ngẫu nhiên tại một số địa điểm ở chợ Thủ Đức;

- Hóa chất: Chất chuẩn $\mathrm{KNO}_{3}$ : sấy khan không lẫn nitrite, nước cất, Natri salixilat, $\mathrm{H}_{2} \mathrm{SO}_{4}$ đậm đặc, $\mathrm{C}_{4} \mathrm{H}_{4} \mathrm{KNaO}_{6} .4 \mathrm{H}_{2} \mathrm{O}, \mathrm{NaOH}$;

- Môi trường nuôi cấy và phân lập: Môi trường Giltay; môi trường $\mathrm{O} / \mathrm{F}$ (môi trường phát hiện khả năng oxy hóa hoặc lên men glucose); môi trường VP-MR (môi trường phát hiện các sản phẩm acid từ quá trình chuyển hóa glucose); môi trường urea (phát hiện enzyme urease); môi trường phenol red lactose broth (khả năng lên men lactose); môi trường nutrient agar (thử khả năng di động);

- Phương pháp nhuộm Gram, khử nitrat, di động, Oxidase, hoạt tính catalase, lên men glucose, lên men lactose, sử dụng citrate, sinh indole, tan chảy gelatinenase;

- Hóa chất ly trích DNA, thực hiện phản ứng và chạy điện di sản phẩm PCR. Dung dịch đệm TE Buffer ( $\mathrm{pH}=8$ ), $\mathrm{CH}_{3} \mathrm{COONa} 3 \mathrm{M}$, cồn $99 \%$, Ethanol 70\%, nước cất khử ion. PCR buffer $0,5 \mathrm{X}$, Gotaq green Master Mix (Promerga, USA) $\mathrm{MgCl}_{2} 2 \mathrm{mM}$, Mỗi dNTP $200 \mu \mathrm{M}$, mồi xuôi $0,5 \mu \mathrm{M}$, mồi ngược $0,5 \mu \mathrm{M}, \mathrm{Taq}$ DNA polymerase $1 \mathrm{IU}$, Agarose $1 \%$, TBE (Tris borate EDTA) $(\mathrm{pH}=8)$ 0,5X, thuốc nhuộm Blue gel loading buffer $6 \mathrm{x}$.

\subsection{Phwơng pháp nghiên cúu}

\subsubsection{Thu thập mẫu}

Cách tiến hành: 10 mẫu dưa cải được mua về để trong hũ nhựa 1 lít đã được vô trùng. Mỗi mẫu dưa cải đem phân tích được lặp lại 3 lần và khảo sát hàm lượng nitrat liên tục trong 5 ngày sau khi ủ chua 1 ngày theo phương pháp so màu với natrisalicylate. 


\subsubsection{Khảo sát hàm lương nitrat trong mẫu dura cải muối chua bằng phương pháp so} màu với Natri salicylate

Hợp chất nitrat trong mẫu phản ứng với Natri salixylate trong môi trường axit cho một phức có màu vàng của muối axit nitrosalixylic. Sau đó đo độ hấp thụ quang ở bước sóng 410 nm. Phương pháp xác định theo TCVN 4562-88.

2.2.3. Phân lập, tuyển chọn và kiểm tra chủng vi khuẩn có khả năng chuyển hóa nitrat trong dua cải muối chua

Lấy 10 mẫu dưa cải đã được thu mua, pha loãng các mẫu nước dưa cải ở các nồng độ $10^{2}, 10^{-3}, 10^{-4}, 10^{-5}$ bằng nước cất vô trùng. Cho $15 \mathrm{ml}$ môi trường thạch đặc trưng Giltay đã tiệt trùng vào đĩa petri. Dùng micropipet hút $0,1 \mathrm{ml}$ mẫu nước dưa cải pha loãng $10^{-5}$ dàn đều trên mặt thạch bằng que gạt thủy tinh vô trùng. Sau đó ủ ở nhiệt độ $37^{\circ} \mathrm{C}$ trong vòng 24 giờ. Chọn lọc những khuẩn lạc tròn, có màu trắng sữa, đục, có khả năng mọc trên môi trường nuôi cấy, tiến hành cấy phân lập và làm thuần cũng trên môi trường Giltay (Nguyen, 2009). Các chủng sau khi được làm thuần và được hoạt hóa trên môi trường thạch nghiêng ủ ở nhiệt độ phòng trong thời gian 18-24 giờ. Sau đó, thực hiện nhuộm Gram và thử khả năng khử nitrat bộ test $\mathrm{NO}_{3}$. Lựa chọn 2 chủng vi khuẩn có khả năng chuyển hóa nitrat cao nhất.

Các chủng vi khuẩn có khả năng chuyển hóa nitrat trên môi trường Giltay, được nuôi cấy trong môi trường dịch thể nitrat, lần lượt thực hiện các thử nghiệm sinh hóa: thử nghiệm di động, catalase, oxydase, thử nghiệm $\mathrm{O} / \mathrm{F}$, lên men lactose, len men glucose, thử nghiệm citrate, indole, VP, gelatine, thử nghiệm urea. Việc kiểm tra thêm các đặc tính sinh hóa khác sẽ giúp ích cho việc định danh các chủng phân lập được. Vi khuẩn sẽ được phân loại dựa theo khoá phân loại của Bergey và Breed (1957).

2.2.4. Bổ sung vi khuẩn vào quy trình muối chua dua cải và xác định hàm lương nitrat trong mẫu dua cải bằng phương pháp so màu với natrisalicylate

Thí nghiệm được bố trí nhằm đánh giá khả năng khử nitrat trong dưa cải của các chủng phân lập được. Các nghiệm thức được bố trí trong hũ nhựa 1 lít, mỗi hũ chứa $500 \mathrm{~g}$ dưa cải. Thí nghiệm gồm 4 nghiệm thức $(\mathrm{NT})$ : 3 nghiệm thức có bổ sung vi khuẩn chuyển hóa nitrat và một nghiệm thức đối chứng, mỗi nghiệm thức lặp lại 3 lần. Thông qua quá trình khảo sát quy trình muối chua dưa cải ở quanh khu chợ Thủ Đức đồng thời tham khảo các tài liệu liên quan. Tiến hành muối chua dưa cải với thời gian thử nghiệm là 5 ngày.

Nghiệm thức 1 (ĐC): muối dưa cải không bổ sung vi khuẩn.

Nghiệm thức 2: bổ sung $1 \mathrm{ml}\left(10^{6}-10^{7} \mathrm{cfu} / \mathrm{ml}\right)$ canh trường chủng M1.

Nghiệm thức 3: bổ sung $1 \mathrm{ml}\left(10^{6}-10^{7} \mathrm{cfu} / \mathrm{ml}\right)$ canh trường chủng M2.

Nghiệm thức 4 : bổ sung kết hợp $0,5 \mathrm{ml}$ canh trường chủng $\mathrm{M} 1$ và $0,5 \mathrm{ml}$ canh trường chủng M2 có mật độ khoảng $10^{6}-10^{7} \mathrm{cfu} / \mathrm{ml}$.

Cách tiến hành: Môi trường dịch thể nitrat (Tran, 2002) được chuẩn bị trong 2 bình tam giác $250 \mathrm{ml}$ với $100 \mathrm{ml}$ môi trường/bình và được hấp khử trùng ở $121^{\circ} \mathrm{C}$ trong 20 phút. Cấy chủng $\mathrm{M} 1$ và $\mathrm{M} 2$ từ ống thạch nghiêng vào môi trường đã chuẩn bị, mang đi lắc ở nhiệt độ $37^{\circ} \mathrm{C}$ với tốc độ lắc 100 vòng/phút trong 48 giờ. Canh trường vi khuẩn sau 48 giờ nuôi cấy thu 
dịch dùng để bổ sung vào các nghiệm thức đồng thời xác định mật độ vi khuẩn tại thời điểm sau $48 \mathrm{~h}$.

- Phương pháp xác định hàm lượng nitrat sau khi muối chua dưa cải bằng phương pháp so màu với natrisalycilate theo TCVN 4562-88, tiến hành khảo sát liên tục trong 5 ngày;

- Phương pháp đánh giá các thông số môi trường thí nghiệm: tiến hành đo $\mathrm{pH} 1$ lần/ngày vào lúc 8 giờ bằng máy đo $\mathrm{pH}$. Mẫu dưa cải được đánh giá vào 2 thời điểm sau ngày lên men thứ nhất và thứ năm để xác định lượng acid tổng số bằng phương pháp chuẩn độ Therne;

- Xác định mật độ tế bào vi khuẩn chuyển hóa nitrat ở ngày thứ nhất và thứ năm sau khi muối dưa.

\subsection{Phương pháp phân tích}

\subsubsection{Xác định hàm lượg nitrat trong dưa cải muối chua}

Công thức xác định hàm lượng nitrate dựa vào phương trình đường chuẩn nitrate bằng phương pháp quang phổ UV-Vis. Hàm lượng nitrat trong $1 \mathrm{~kg}$ dưa cải được tính theo công thức như sau $(\mathrm{mg} / \mathrm{kg})$ :

$$
\frac{C x * V \mathbf{d} m 1 * V \mathbf{a} m 2 * K * 62}{m * n * 101}
$$

$\mathrm{C}_{\mathrm{x}}$ nồng độ $\mathrm{NO}_{3}{ }^{-}$tính theo đường chuẩn $(\mathrm{mg} / \mathrm{l}) ; \mathrm{V} đ \mathrm{~m} 1$ là thể tích định mức $-400 \mathrm{ml}$; Vđm2 là thể tích định mức khi cho thuốc thử - 13ml; K độ pha loãng - 20; $\mathrm{m}$ khối lượng mẫu phân tích - $50 \mathrm{~g}$; n là thể tích hút mẫu để đo $\mathrm{OD}, 5 \mathrm{ml}$.

\subsection{2. Định danh vi khuẩn bằng kỹy thuật sinh học phân tử}

Tách chiết DNA vi khuẩn bằng phương pháp đun sôi: Mẫu vi khuẩn được nuôi cấy tăng sinh ở nhiệt độ $37^{\circ} \mathrm{C}$ trong 24 giờ. Sau đó hút $1 \mathrm{ml}$ tăng sinh vi khuẩn cho vào ống tube eppendorf $1,5 \mathrm{ml}$ ly tâm 8000 vòng/phút trong 3 phút, loại bỏ dịch nuôi cấy thu kết tủa. Sau đó thêm $300 \mu 1$ TE buffer, votex để trộn đều tế bào vi khuẩn. Cho vào nồi nước đang sôi ở $100^{\circ} \mathrm{C}$ trong vòng 15 phút. Sau đó sốc nhiệt ở $-20^{\circ} \mathrm{C}$ trong 5 phút và ly tâm 13000 vòng/phút trong 5 phút. Tiếp tục hút $200 \mu 1$ dung dịch nổi phía trên cho vào ống tube $1,5 \mathrm{ml}$ mới, cho thêm $20 \mu 1 \mathrm{CH}_{3} \mathrm{COONa}$, $600 \mu 1$ Etanol $70 \%$ ủ trong tủ $-20^{\circ} \mathrm{C}$ trong 1 đến 2 giờ. Ly tâm 13000 vòng/phút, bỏ dịch nổi để

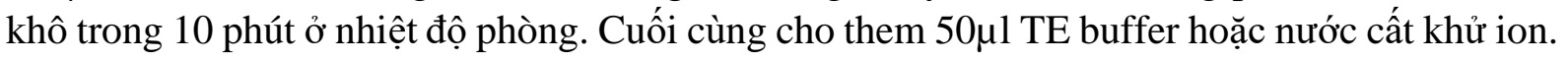
Bảo quản mẫu DNA ở $-20^{\circ} \mathrm{C}$.

Phản ứng tiến hành với cặp mồi không chuyên biệt nhằm khuếch đại vùng gen 16SrRNA16S-rRNA-F(5'-AGAGTTTGATCCTGGCTCAG-3');

16S-rRNA-R(5'AAGGAGGTGATCCAGCCGCA-3') (Rezaee, Godini, Dehestani, \& Kaviani, 2010). Thực hiện phản ứng PCR với tổng thể tích $25 \mu \mathrm{l}$ : $1,25 \mu 1$ primer-F; $1,25 \mu 1$ primer-R; $1 \mu 1$ mẫu DNA; $12,5 \mu \mathrm{l}$ GoTaq polymerase vào ống tube PCR. Bổ sung thêm $9 \mu \mathrm{l}$ nước cất khử ion. Tất cả đều được trộn đều trước khi thực hiện phản ứng PCR. Quy trình chạy phản ứng PCR theo chương trình luân nhiệt như sau: $95^{\circ} \mathrm{C}$ trong 4 phút, sau đó lặp lại 30 chu kỳ với các bước như sau: Biến tính $95^{\circ} \mathrm{C}$ trong 30 giây, bắt cặp mồi ở $53^{\circ} \mathrm{C}$ trong 30 giây, tổng hợp DNA ở $72^{\circ} \mathrm{C}$ trong 1 phút. Cuối cùng phản ứng duy trì ở $72^{\circ} \mathrm{C}$ trong 5 phút. Bảo quản ở $4^{\circ} \mathrm{C}$. Sản phẩm PCR được điện di 
trên gel agarose 1\%, trong dung dịch đệm TBE buffer 0,5X ở 100V, 90mA trong 20 phút. Trộn đều mẫu và loader với tỉ lệ: $0,5 \mu 1$ loadingdye buffer $6 \mathrm{X}$ và $5 \mu 1$ sản phẩm $\mathrm{PCR}$ vào trong các giếng của gel và được chụp bằng máy đọc và chụp ảnh gel MultiDa-lt Digital Imaging System. Thang chuẩn 100bp được mua từ công ty Fermentas.

Sản phẩm PCR vùng 16S-rRNA được gửi giải trình tự tại công ty First Base, Malaysia. Trình tự của sản phẩm PCR được so sánh với trình tự $16 \mathrm{~S}$ rRNA của các loài vi khuẩn Bacillus khác trên ngân hàng gen bao gồm: B.firmus (HQ397586.1); B. thuringiensis (KJ000207.1); B.infantis (KT719573.1); B.drentensis (KM041133.1); B. megaterium (KF419123.1); B.aryabhattai (KP706808.1); B. cereus (KR709243.1); B. pumilus (KT273321.1); B.safensis (KP940383.1); B.amyloliquefaciens (KR010178.1); B. methylotrophicus (KT216570.1); B. vallismortis (KT216619.1); B. subtilis (KP699121.1); B. tequilensis (HF562894.1); B. licheniformis (KT274776.1); B. sonorensis (KP296232.1) và Pseudomonas putida (EU833948.1) thông qua việc sử dụng chương trình BLAST (National Center got Biotechnology Information, Bethesda, MD). Cây di truyền của những trình tự này được xây dựng bằng phương pháp Neighbor-joining trong phần mềm Mega 6.0 với 1000 lần lặp lại (Tamura \& Kumar, 2002).

\section{Kết quả và thảo luận}

\subsection{Kết quả khảo sát hàm lự̛ng nitrat có trong dưa cải muối chua}

Xác định hàm lượng nitrat định kỳ 24 giờ một lần liên tục trong 5 ngày. Kết quả được thể hiện ở Hình 1.

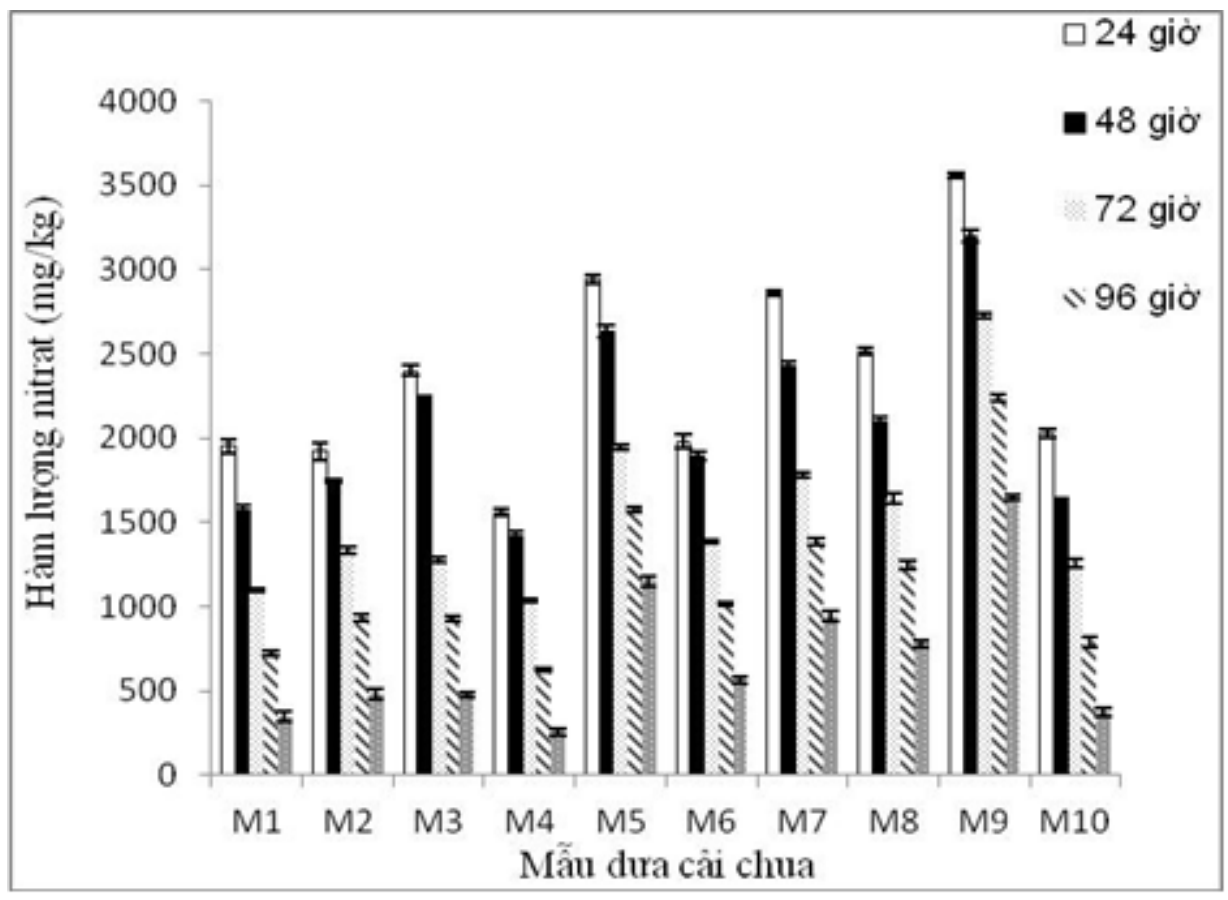

Hình 1. Biểu đồ thể hiện sự biến thiên hàm lượng nitrat trong dưa cải theo thời gian

Sau khi khảo sát hàm lượng nitrat trên 10 mẫu dưa cải trong 5 ngày liên tiếp nhận thấy phần lớn các mẫu dưa cải đều có hàm lượng nitrat vượt mức cho phép của WHO (2.000 - 
$5.000 \mathrm{mg} / \mathrm{kg}$, so với ngưỡng cho phép của WHO về hàm lượng nitrat có trong rau, củ từ 60 $1.500 \mathrm{mg} / \mathrm{kg}$ ). Dựa vào Hình 1 cho thấy ở thời điểm lên men sau 96 giờ hoặc 120 giờ tỷ lệ mẫu nằm trong giới hạn cho phép WHO đạt $100 \%$ trên tất cả các mẫu phân tích. Thông thường người tiêu dùng đều sử dụng dưa cải trong khoảng 48 hoặc 72 giờ lên men. Như vậy, khả năng người tiêu dùng bị ngộ độc hoặc mắc bệnh rất cao nếu ăn liên tục dưa cải trong thời gian đó, do đó khuyến cáo mọi người nên bắt đầu sử dụng dưa cải vào thời điểm sau 96 giờ hoặc 120 giờ lên men. Nhưng điều này lại không có khả thi vì dưa cải sau khi lên men 48 giờ đến 72 giờ đã đạt được độ chua, giòn, màu sắc đặc trưng của sản phẩm muối chua. Sau 96 giờ đến 120 giờ lên men mà hàm lượng nitrat nằm ở mức an toàn thì chất lượng cảm quan của sản phẩm lại không tốt, dưa quá chua hoặc không còn mùi thơm đặc trưng. Vì vậy, phân lập chủng vi khuẩn chuyển hóa nitrat để bổ sung vào dưa cải muối chua làm giảm hàm lượng nitrat trong dưa cải là một điều cần thiết.

\subsection{Kết quả phân lập, tuyển chọn và kiểm tra chủng vi khuẩn có khả năng chuyển hóa nitrat trong dua cải muối chua}

Từ 10 mẫu dưa cải thu thập được ở các địa điểm tại chợ Thủ Đức tiến hành phân lập và đếm các chủng vi khuẩn chuyển hóa nitrat trên môi trường Giltay với cơ chất $\mathrm{KNO}_{3}$ và ủ 24 giờ ở nhiệt độ phòng. Dựa vào đặc điểm khuẩn lạc đã phân lập được 6 chủng vi khuẩn khử nitrat trên môi trường Giltay từ 10 mẫu dưa cải. Các chủng phân lập được ký hiệu thứ tự M1, M2, M3, M4, M5, M6. Đặc điểm các khuẩn lạc phân lập trên môi trường Giltay.

\section{Bảng 1}

Đặc tính các khuẩn lạc phân lập trên môi trường Giltay

\begin{tabular}{cl}
\hline Chủng phân lập & \multicolumn{1}{c}{ Đặc điểm khuẩn lạc } \\
\hline M1 & Màu trắng đục, tròn, rìa răng cưa không đều, có tâm \\
M2 & Màu trắng sữa, tròn, bề mặt lồi, bóng, ướt \\
M3 & Màu trắng đục, tròn nhỏ, lồi \\
M4 & Màu trắng sữa, nhỏ, lồi \\
M5 & Màu trắng đục, tròn dẹp, có vòng đậm màu trên bề mặt, khô \\
M6 & Màu trắng sữa, lồi, rìa khuẩn lạc không đều \\
\hline
\end{tabular}

Nguồn: Kết quả phân tích dữ liệu của nhóm nghiên cứu

Hầu hết các khuẩn lạc phân lập trên môi trường Giltay đều có màu trắng sữa hoặc trắng đục, tròn lồi hoặc dẹp, thể hiện sự phong phú của các chủng vi khuẩn chuyển hóa nitrat (Nguyễn Thị Tuyền và cộng sự, 2009). 


\section{Bảng 2}

Đặc điểm nhuộm Gram của các mẫu được phân lập

\begin{tabular}{|c|c|c|c|}
\hline Chủng & Gram & Hình thái & Kích thước \\
\hline M1 & + & Que & $1,5-2$ \\
\hline M2 & + & Que & $1-1,5$ \\
\hline M3 & - & Que & $1-1,5$ \\
\hline M4 & + & Que & $1-1,5$ \\
\hline M5 & - & Cầu & $0,5-1$ \\
\hline M6 & - & Que & $0,5-1$ \\
\hline
\end{tabular}

Nguồn: Kết quả phân tích dữ liệu của nhóm nghiên cứu

Kết quả nhuộm Gram 6 chủng vi khuẩn khử nitrat trên môi trường Giltay cho thấy các chủng vi khuẩn M3, M6 có đặc điểm là trực khuẩn Gram (-), ba chủng $\mathrm{M} 1, \mathrm{M} 2$ và $\mathrm{M} 4$ là trực khuẩn Gram (+) và M5 là cầu khuẩn Gram (-).

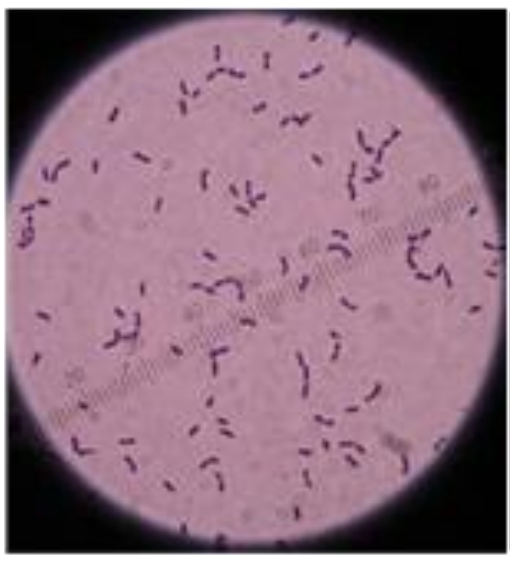

(a)

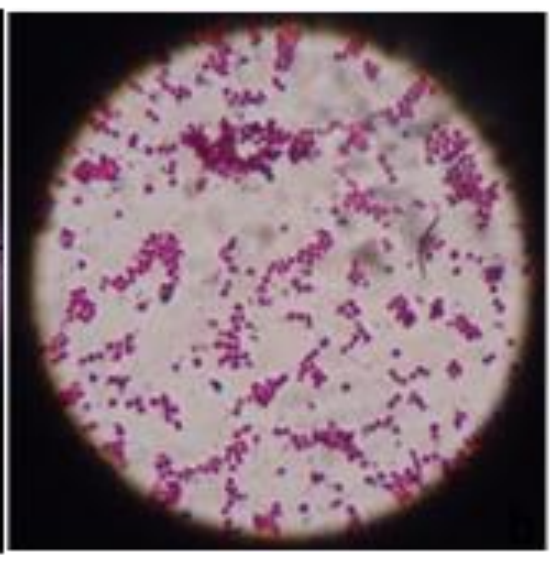

(b)

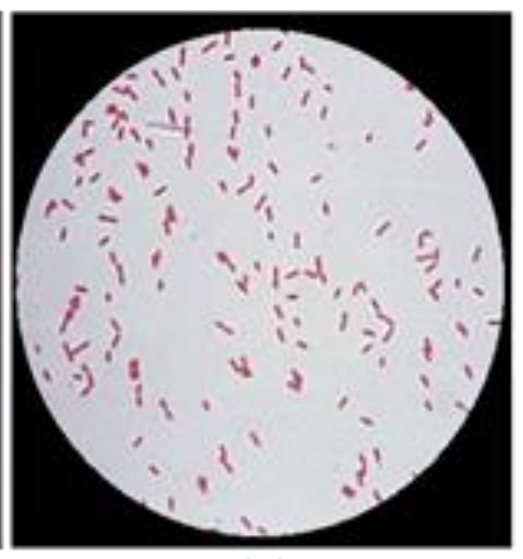

(c)

Hình 2. Kết quả nhuộm Gram. (a) trực khuẩn Gram +; (b) cầu khuẩn Gram -; (c) trực khuẩn Gram - (độ phóng đại 100x)

Nhằm tìm ra chủng có khả năng khử nitrat cao nhất để bổ sung vào dưa cải, tiến hành sàng lọc bằng phản ứng khử nitrat với bộ test $\mathrm{NO}_{3}$. Sau khi nuôi cấy trên môi trường dịch thể nitrat trong 24 giờ, thử khả năng khử nitrat của 6 chủng bằng bộ test $\mathrm{NO}_{3}$ Sera dựa trên nguyên tắc so màu. Khi cho thuốc thử vào canh khuẩn nhận thấy hai chủng $\mathrm{M} 1$ và $\mathrm{M} 2$ có màu nhạt nhất trong 6 chủng, điều này chứng tỏ khả năng khử nitrat 2 chủng này cao hơn so với các chủng còn lại.

Hai chủng M1 và M2 được chọn để tiếp tục thực hiện các thử nghiệm sinh hóa. Kết quả được thể hiện trong Bảng 3 như sau: 


\section{Bảng 3}

Một số phản ứng sinh hóa dùng để định danh chủng M1 và M2

\begin{tabular}{|c|c|c|}
\hline \multirow{2}{*}{ Thử nghiệm } & \multicolumn{2}{|c|}{ Kết quả } \\
\hline & M1 & M2 \\
\hline Gram, hình thái & dương, hình que & dương, hình que \\
\hline Khử nitrate & + & + \\
\hline Di động & + & + \\
\hline Oxidase & + & - \\
\hline Hoạt tính catalase & + & + \\
\hline Urease & + & + \\
\hline $\mathrm{O} / \mathrm{F}$ & + & + \\
\hline Lên men glucose & + & + \\
\hline Lên men lactose & - & - \\
\hline Sử dụng citrate & + & + \\
\hline Sinh indole & - & - \\
\hline MR & + & + \\
\hline VP & + & - \\
\hline Tan chảy Gelatinenase & + & + \\
\hline
\end{tabular}

Chú thích: + (dương tính); - (âm tính)

Nguồn: Kết quả phân tích dữ liệu của nhóm nghiên cứu

Theo Pashley và cộng sự (2004) thì nhóm vi khuẩn khử nitrate thường là các vi khuẩn khử: Bacillus, Pseudomonas, Methanomonas, Paracoccus, Spirillum, và Thiobacillus, Achromobacterium, Denitrobacillus, Micrococcus, Xanthomonas đều có khả năng khử nitrate và phản ứng catalase (+). Chủng $\mathrm{M} 1, \mathrm{M} 2$ dương tính với hai phản ứng này, do đó dựa vào đặc điểm hình thái khuẩn lạc có màu trắng đục, tròn, rìa răng cưa không đều, là trực khuẩn Gram 
(+) thì chủng M1, M2 có thể là Bacillus spp. Dựa theo phương pháp nhận diện các chủng vi sinh vật thì chủng $\mathrm{M} 1, \mathrm{M} 2$ có kết quả sinh hóa: Gram (+), trực khuẩn, khả năng di động (+), Catalase $(+)$, thử nghiệm $\mathrm{O} / \mathrm{F}(+/-)$, lên men lactose (-) điều này đúng với nghiên cứu của Ray, Datta, Bhadra, Chaudhuri, và Mitra (2012), Dunca, Creanga, Ailiesei, và Nimitan (2005).

\subsection{Bổ sung vi khuẩn vào quy trình muối chua dưa cải và xác định hàm lựng nitrat trong mẫu dua cải bằng phương pháp so màu với natrisalicylate}

Các mẫu dưa cải từ các nghiệm thức sau khi được ly trích tiến hành xác định hàm lượng nitrat bằng phương pháp so màu với Natri salicylate. Kết quả được thể hiện ở Bảng 4.

\section{Bảng 4}

Hàm lượng nitrat trong thời gian lên men

\begin{tabular}{ccccc}
\hline \multirow{2}{*}{$\begin{array}{c}\text { Nghiệm } \\
\text { thức }\end{array}$} & \multicolumn{4}{c}{ Nồng độ nitrat $(\mathbf{m g} / \mathbf{k g})$} \\
\cline { 2 - 5 } & Đối chứng & Bổ sung M1 & Bổ sung M2 & Bổ sung M1, M2 \\
\hline 24 giờ & $2402,70^{\mathrm{a}}$ & $2071,00^{\mathrm{ab}}$ & $2312,30^{\mathrm{a}}$ & $1850,2^{\mathrm{b}}$ \\
48 giờ & $1641,60^{\mathrm{a}}$ & $1382,30^{\mathrm{b}}$ & $1254,10^{\mathrm{b}}$ & $717,40^{\mathrm{c}}$ \\
72 giờ & $818,38^{\mathrm{a}}$ & $554,90^{\mathrm{b}}$ & $684,13^{\mathrm{ab}}$ & $512,85^{\mathrm{b}}$ \\
96 giờ & $554,92^{\mathrm{a}}$ & $442,40^{\mathrm{b}}$ & $406,47^{\mathrm{b}}$ & $280,90^{\mathrm{c}}$ \\
120 giờ & $267,850^{\mathrm{a}}$ & $249,41^{\mathrm{a}}$ & $221,03^{\mathrm{b}}$ & $227,25^{\mathrm{b}}$ \\
\hline
\end{tabular}

Ghi chú: Số liệu trong bảng là giá trị trung bình của 3 lần lặp. Trong cùng một hàng, các giá trị trung bình có ký tự theo sau khác nhau có sự khác biệt ý nghĩa về mặt thống kê $(\mathrm{P}<0,05)$

Nguồn: Kết quả phân tích dữ liệu của nhóm nghiên cứu

Kết quả thí nghiệm khảo sát hàm lượng nitrat trong dưa cải được trình bày trong Bảng 4, có ba nghiệm thức có bổ sung vi khuẩn sau 24 giờ lên men vẫn ở nồng độ cao trên $1500 \mathrm{mg} / \mathrm{kg}$, bắt đầu giảm mạnh sau 48 và 72 giờ lên men, tiếp tục giảm từ từ vào những thời điểm lên men sau 96 và 120 giờ tiếp theo. Khi chuyển vi khuẩn chuyển hóa nitrate từ môi trường dịch thể nitrate vào quy trình muối chua mới theo truyền thống thì vi khuẩn sẽ phát triển chậm để thích nghi trong khoảng thời gian ngắn (pha lag). Cùng thời gian ấy, vi khuẩn lactic hoạt động mạnh tạo acid lactic cho quá trình lên men đã làm giảm $\mathrm{pH}$, điều này làm giảm mức độ khử nitrat của hai chủng bổ sung vào. Điều này đúng với nghiên cứu của Cavigelli và Robertson (2000), Stensel and Horne (2000). Hàm lượng nitrat của các nghiệm thức bổ sung M1, bổ sung M2, bổ sung kết hợp $\mathrm{M} 1$ và $\mathrm{M} 2$ giảm nhanh và đạt ngưỡng cho phép ngay tại thời điểm dưa bắt đầu sử dụng được tức sau 48 giờ lên men thì ở mẫu đối chứng hàm lượng nitrat có giảm nhưng vẫn ở mức cao so với ngưỡng cho phép. Điều này chứng tỏ các mẫu có bổ sung vi khuẩn cho kết quả tốt hơn những mẫu không bổ sung vi khuẩn. Đồng thời ở thời điểm này, dưa đã đạt chất lượng cảm quan, có màu vàng, chua dịu và hương thơm đặc trưng lại phù hợp với thời gian các tiểu thương đem bán ra thị trường. Ba nghiệm thức có bổ sung vi khuẩn: $\mathrm{M} 1 ; \mathrm{M} 2 ; \mathrm{M} 1$ và $\mathrm{M} 2$ cũng có sự khác biệt về hàm lượng nitrat theo thời gian 24 giờ, 48 giờ, 72 giờ, 96 giờ và 120 giờ. Nghiệm thức kết hợp cả hai chủng M1, M2 cho hiệu quả cao nhất so với các nghiệm thức bổ sung riêng lẻ từng chủng $\mathrm{M} 1$ và $\mathrm{M} 2$. Vì vậy, chọn nghiệm thức này để áp dụng cho quy trình muối chua dưa cải có bổ sung vi khuẩn khử nitrat. 


\subsection{Kết quả định danh bằng kỹy thuật sinh học phân tử}

Quy trình tách chiết DNA tổng số của vi khuẩn mẫu M1, M2 từ dưa cải muối chua được ly trích bằng phương pháp đun sôi (Costa et al., 2009), cho kết quả tách chiết ổn định, lượng DNA tinh sạch với tỉ lệ 260/280 =1,9 (tỉ lệ 260/280 =1,8 - 2 là thích hợp). Sau đó, tiến hành thực hiện phản ứng PCR và điện di sản phẩm PCR mẫu DNA của M1, M2. Kết quả cho thấy rằng có sự hiện diện gen $16 \mathrm{~S}$ rRNA của các chủng vi khuẩn chuyển hóa nitrate lần lượt là $\mathrm{M} 1$, $\mathrm{M} 2$. Chủng vi khuẩn chuyển hóa nitrat $\mathrm{M} 1$ được định danh bằng phương pháp giải trình tự cho tiểu phần ribosome $16 \mathrm{~S}$. Trình tự được tra cứu trên ngân hàng gen của NCBI thông qua chương trình BLAST và dựa vào sự tương đồng trong trình tự của đoạn gen để định danh đến loài. Kết quả cho thấy, trình tự DNA $16 \mathrm{~S}$ của chủng $\mathrm{M} 1$ khi đối chiếu với trình tự gen của chủng Bacillus aryabhattai IHB B 7238 16S ribosomal RNA ở ngân hàng gen có độ tương đồng đạt đến 99\%. Vì vậy, chủng M1 tương đồng với loài Bacillus aryabhattai. Tương tự như vậy, trình tự DNA $16 \mathrm{~S}$ của chủng M2 khi đối chiếu với trình tự gen của chủng Bacillus megaterium Jz11 16S ribosomal RNA ở ngân hàng gen có độ tương đồng đạt đến 100\%. Vì vậy, chủng M2 tương đồng với loài Bacillus megaterium. Bên cạnh đó, kết quả phân tích phả hệ phân tử trên cây phát sinh loài Neighbor-joining với giá trị bootstrap 1000 lần cho thấy M1 và M2 thuộc giống Bacillus, loài Bacillus aryabhattai (Hình 3).

Chủng vi khuẩn Bacillus megaterium, Bacillus aryabhattai được ứng dụng rộng rãi trong công nghệ sinh học, thực phẩm, dược phẩm và các ngành công nghiệp khác như: Bacillus megaterium một loại vi khuẩn sản xuất các enzyme thủy phân amylase, protease, chitanase, phytase v.v... (Alippi \& Reynaldi, 2006; Padgham \& Sikora, 2007). Trong công nghệ sinh học, Bacillus megaterium dùng làm phân bón vi sinh. Bacillus aryabhattai tổng hợp peptide, quản lý chất thải từ các ngành công nghiệp chế biến thực phẩm khác nhau (Sharma, Singh, \& Gupta, 2014). 


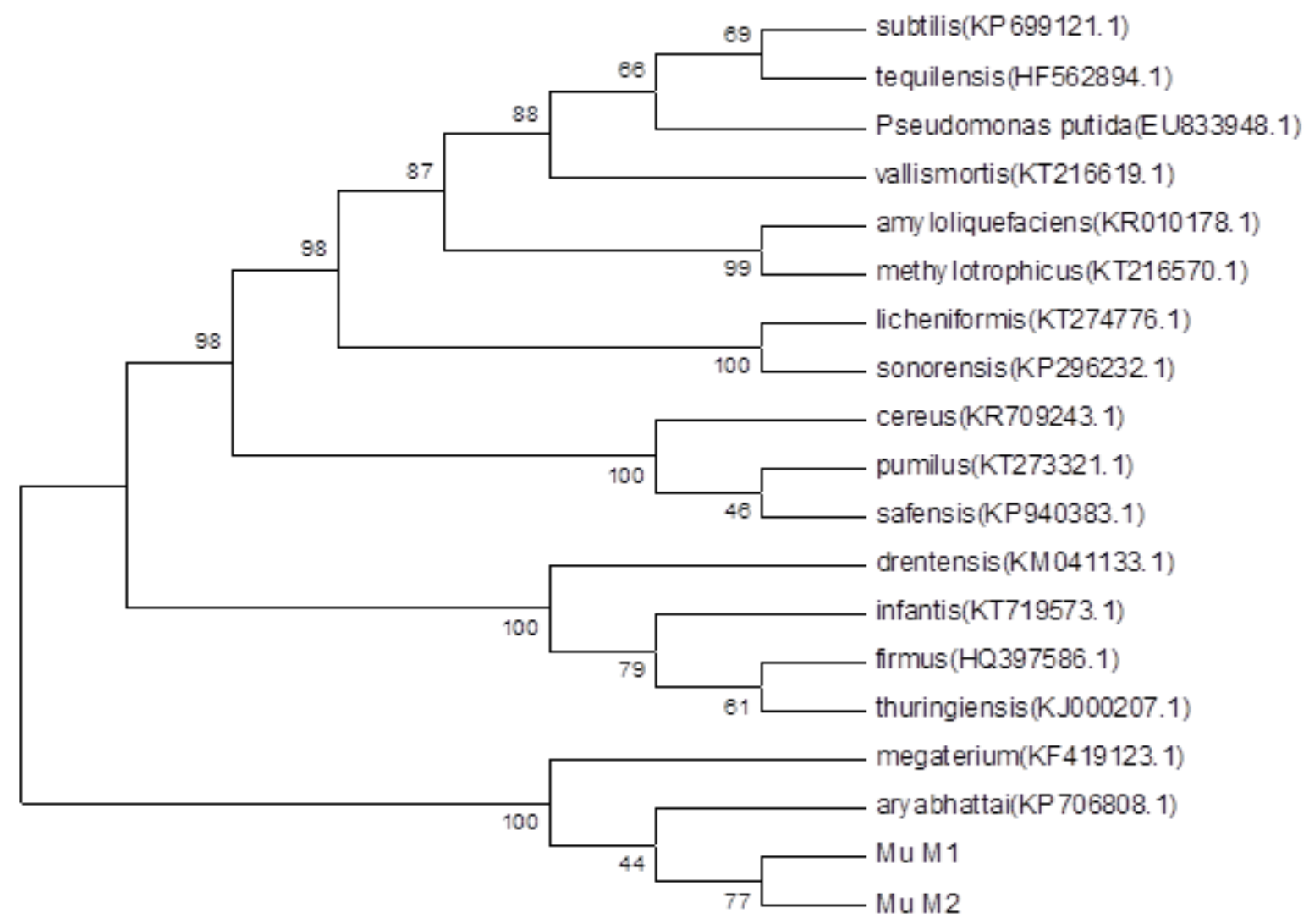

Hình 3. Cây thư mục di truyền phát sinh loài dựa trên trình tự $16 \mathrm{~S}$ rRNA được xây dựng bằng phần mềm MEGA 6.06, theo phương pháp Neighbor-joining với độ lặp lại là 1000 lần

\section{Kết luận}

Kết quả nghiên cứu bước đầu cho thấy các mẫu dưa cải được thu thập có hàm lượng nitrat không đạt tiêu chuẩn theo quy định của Tổ chức $\mathrm{Y}$ tế thế giới. Bên cạnh đó chúng tôi đã phân lập được 6 chủng vi khuẩn chuyển hóa nitrat và tuyển chọn được 2 chủng $\mathrm{M} 1$ và $\mathrm{M} 2$ có khả năng xử lý nitrat cao nhất trên môi trường Giltay. Kết quả khảo sát hàm lượng nitrat trong dưa cải ở các mẫu bổ sung vi khuẩn $\mathrm{M} 1, \mathrm{M} 2$ cho thấy hàm lượng nitrat thấp hơn so với những mẫu không bổ sung vi khuẩn. Ngoài ra, kết quả định danh bằng kỹ thuật sinh học phân tử bằng bộ kit Promega với 2 chủng $\mathrm{M} 1$ và $\mathrm{M} 2$ có kích thước tương ứng là 1153bp 509bp, kết hợp phân tích kết quả truy vấn tự động trên NCBI (Blast) và phân tích phả hệ phân tử trên cây phát sinh loài Neighbor-joining định danh hai sản phẩm $\mathrm{M} 1$ và $\mathrm{M} 2$ là Bacillus aryabhattai. Do đó, việc mở rộng nghiên cứu ra nhiều khu vực hoặc các tỉnh khác để làm phong phú nguồn vi khuẩn chuyển hóa nitrat phục vụ cho quá trình nghiên cứu và ứng dụng trong lĩnh vực công nghiệp thực phẩm là cần thiết.

\section{Tài liệu tham khảo}

Alippi, A., \& Reynaldi, F. J. (2006). Inhibition of the growth of Paenibacillus larvae, the causal agent of American foulbrood of honeybees, by selected strains of aerobic spore-forming 
bacteria isolated from apiarian sources. Journal of Invertebrate Pathology, 91(3), 141146. doi:10.1016/j.jip.2005.12.002

Bergey, D. H., \& Breed, R. S. (1957). Bergey's manual of determinative bacteriology. Baltimore, NY: Williams \& Wilkins Company.

Cavigelli, M. A., \& Robertson, G. P. (2000). The functional significance of denitrifier community composition in a terrestrial ecosystem. Ecology, 81(5), 1402-1414. doi:10.1890/0012-9658(2000)081[1402:TFSODC]2.0.CO;2

Chan, T. Y. K. (2011). Vegetable-borne nitrate and nitrite and the risk of methaemoglobinaemia. Toxicology Letters, 200(1/2), 107-108.

Chao, S.-H., Wu, R.-J., Watanabe, K., \& Tsai, Y.-C. (2013). Diversity of lactic acid bacteria insuan-tsaiandfu-tsai, traditional fermented mustard of Taiwan. International Journal of Food Microbiology, 135(3), 203-210.

Costa, K., Navarro, J., Shock, E. L., Zhang, C., Soukup, D., \& Hedlund, B. (2009). Microbiology and geochemistry of great boiling and mud hot springs in the United States Great Basin. Extremophiles, 13(3), 447-459.

Dunca, S., Creanga, D., Ailiesei, O., \& Nimitan, E. (2005). Microorganisms growth with magnetic fluids. Journal of Magnetism and Magnetic Materials, 289, 445-447. doi:10.1016/j.jmmm.2004.11.125

Greer, F. R., Shannon, M. D., American academy of pediatrics committee on nutrition, \& American academy of pediatrics committee on environmental health. (2005). Infant methemoglobinemia: The role of dietary nitrate in food and water. Pediatrics, 116(3), 784-786.

Huynh, T. V., Cao, D. N., \& Truong, N. T. (2015). Tối ưu hóa khả năng tổng hợp chất kết tụ sinh học của chủng vi khuẩn Bacillus aryabhattai KG12S và thử nghiệm xử lý nước thải sau Biogas từ trại chăn nuôi heo [Optimization of bio-agglutination synthesis of Bacillus aryabhattai KG12S strain and biogas post-Biogas wastewater treatment from swine farms]. Tạp chí Khoa học Trương Đại học Cần Tho. Phần B: Nông Nghiệp, Thủy sản và Công nghẹ sinh hoc, 37(1), 32-41.

Le, T. K. T., \& Nguyen, L. V. (2012). Phân tích và đánh giá hàm lượng nitrat, nitrit trong một số thực phẩm chế biến lưu hành ở thành phố Huế [Analysis and assessment of nitrate and nitrite content in some processed foods circulating in Hue City]. Tạp chi khoa hoc Đại hoc Huế, 74, 185-191.

Leszczynska, T., Filipiak-Florkiewicz, A., Ciéslik, E., \& Sikora, E., (2009). Effects of some processing methods on nitrate and nitrite changes in cruciferous vegetables. Journal of Food Composition and Analysis, 22(4), 315-321.

Nguyen, H. H. (2009). Giáo trình thục hành vi sinh úng dụng [Curriculum for practicing applied microbiology]. Ho Chi Minh, Vietnam: Trường ĐH Kỹ Thuật Công Nghệ TP. Hồ Chí Minh. 
Padgham, J., \& Sikora, R. A. (2007). Biological control potential and modes of action of Bacillus megaterium against Meloidogyne graminicola on rice. Crop Protection, 26(7), 971-977. doi:10.1016/j.cropro.2006.09.004

Park, K. Y., \& Cheigh, H. S. (1992). Kimchi and nitrosamines. Korean Journal of Food Nutrition, 21, 109-116.

Pashley, D. H., Tay, F., Yiu, C., Hashimoto, M., Breschi, L., Carvalho, R. M., \& Ito, S. (2004). Collagen degradation by host-derived enzymes during aging. Journal of Dental Research, 83(3), 216-221. doi:10.1177/154405910408300306

Pham, N. T. T. (2011). Úng dụng các dòng Bacillus sp. có ích trong nuôi trồng thủy sản [Application of Bacillus sp. useful in aquaculture]. Retrieved May 1, 2018, from http://uv-vietnam.com.vn/ NewsDetail.aspx?newsId=1097

Quach, D., Nguyen, T. V., \& Nguyen, T. V. (2008). Bảo quản và chế biến rau quả [Preservation and processing of fruits and vegetables]. Hanoi, Vietnam: Nhà xuất bản Khoa học và Kỹ thuật.

Ray, S., Datta, R., Bhadra, P., Chaudhuri, B., \& Mitra, A. K. (2012). From space to earth: Bacillus aryabhattai found in the Indian sub-continent. Bioscience Discovery, 3(1), 138145.

Rezaee, A., Godini, H., Dehestani, S., \& Kaviani, S. (2010). Isolation and characterization of a novel denitrifying bacterium with high nitrate removal: Pseudomonas stutzeri. Iranian Journal of Environmental Health Science \& Engineering, 7(4), 313-318.

Santamaria, P. (2006). Nitrate in vegetables: Toxicity, content, intake and EC regulation (review). Journal of the Science of Food and Agriculture, 86(1), 10-17.

Sharma, S., Singh, B., \& Gupta, V. K. (2014). Assessment of imidacloprid degradation by soilisolated Bacillus alkalinitrilicus. Environmental monitoring and assessment, 186(11), 7183-7193.

Spoelstra, S. F. (1985). Nitrate in silage. Grass and Forage Science, 40(1), 1-11.

Tamura, K., \& Kumar, S. (2002). Evolutionary distance extimationunder heterogenous substitution patterns among lineages. Molecular Biology and Environment, 19(1), 17271736.

Tran, T. L. (2002). Phương pháp phân tích vi sinh vật trong nước, thực phẩm và mỹ phẩm [Methods of microbiological analysis in food, water and cosmetics]. Ho Chi Minh, Vietnam: Nhà xuất bản Giáo dục.

World Health Organization (WHO). (2012). Agents classified by the International Agency for Research on Cancer (IARC) monographs, list of classifications by cancer sites with sufficient or limited evidence in humans. Retrieved May 15, 2018, from https://monographs.iarc.fr/agents-classified-by-the-iarc/

Yordanov, N. D., Novakova, E., \& Lubenova, S. (2001). Consecutive estimation of nitrate and nitrite ions in vegetables and fruits by electron paramagnetic resonance spectrometry. Analytica Chimica Acta, 437(1), 131-138. 